\title{
The Correlation Between Body Mass Index and Hypertension in the Elderly
}

\author{
$1^{\text {st }}$ Tin Utami \\ Diploma of Midwifery Study Program Faculty Of Health \\ Harapan Bangsa University tinutami@uhb.ac.id
}

\author{
$2^{\text {nd }}$ Wilis Sukmaningtyas \\ Diploma of Midwifery Study Program Faculty Of Health \\ Harapan Bangsa University \\ wilissukmaningtyas@uhb.ac.id
}

\begin{abstract}
Diseases that are mostly suffered by the elderly include hypertension, heart disease, and diabetes mellitus. One of the non-communicable diseases that cause mortality and morbidity in Indonesia is hypertension, the management of which is commonly practiced at various levels of health facilities. The number of elderly population in Indonesia according to 2016 Susenas data is 22.4 million people or $8.69 \%$ of the population, and hypertension is the most common disease (57.6\%). Several studies have shown that BMI is associated with hypertension. The purpose of this study was to determine the correlation between body mass index and hypertension in the elderly in Tambaksogra Village, Sumbang District, Banyumas Regency.

The type of this research is analytic descriptive research with a retrospective approach. The populations were all the elderly who had hypertension recorded from January to July 2019 with 217 respondents. The sampling technique used is total sampling. The results of this study were processed using the Chi Square test and it was found out that there was a relationship between BMI and hypertension in the elderly with p value <alpha $(0.009<0.05)$.
\end{abstract}

\section{Keywords: BMI, hypertension, elderly}

\section{INTRODUCTION}

The process of aging is a natural process in all living things that is a process of continuous biological change experienced by humans at all levels of age and time that can not be avoided by anyone and essentially in the process of aging there is a setback or decline [1]. Hypertension in the elderly is largely isolated systolic hypertension (HST), increased systolic pressure causes a greater likelihood of stroke and myocardial infarction even though the diastolic pressure is within normal limits (isolated systolic hypertension) [2]

Hypertension is a non-communicable disease which is an important health problem throughout the world because of its high and increasing prevalence and its relationship with cardiovascular disease, stroke, retinopathy and kidney disease [3]. Data on Riskesdas in 2013 mentioned that the prevalence of hypertension in Indonesia on age $\geq 18$ years by $25.8 \%$, the highest in the Pacific Islands (30.9\%), then South Kalimantan (30.8\%), East Kalimantan (29.6\%), West Java $(29.4 \%)$ and North Sulawesi $(27.1 \%)$ [4]. While in
2018 the increase was highest in South Kalimantan (44.1\%), then West Java (40\%), East Kalimantan (38\%) ) and Central Java $(36 \%)$ [5]

The number of elderly people in Desa Tambaksogra is quite large, around 300 people, and the majority of the people actively participate in the elderly Posyandu, which is held every month in each RW Posyandu. The elderly who are recorded mostly have hypertension which is certainly very complex with its characteristics. The purpose of this study was to determine the correlation of body mass index and hypertension in the elderly in Tambaksogra Village, Sumbang District, Banyumas Regency.

\section{METHODS}

The type of this research is analytic descriptive research with a retrospective approach. The populations were all the elderly who had hypertension recorded from January to July 2019 with 217 respondents. The sampling technique used is total sampling. This research was conducted in all elderly Posyandu in Tambaksogra Village

The data were analyzed using univariate and bivariate analysis. The univariate analysis in this study was to describe the characteristics of age, sex, body mass index, and the incidence of hypertension. Bivariate analysis was performed to analyze the correlation between body mass index and blood pressure in the elderly using the chi square test.

\section{RESULT}

\subsection{Characteristics of the elderly}

The results found that the majority of respondents were the early elderly as many as 171 respondents $(78.8 \%)$. The dominant sex was female as many as 137 respondents $(63.1 \%)$, and the major body mass index was overweight as many as 130 respondents (59.9\%). In addition, most of the respondents were normal (non-hypertension) as many as 127 respondents $(58.5 \%)$ (Table 1$)$. 
Table 1 : Distribution of age, sex, hypertension history, family history, and smoking in elderly hypertension

\begin{tabular}{cccc}
\hline Characteristics & Category & $\mathbf{f}$ & \% \\
& Early elderly & 171 & 78.8 \\
\multirow{2}{*}{ Age } & Late elderly & 46 & 21.2 \\
\hline \multirow{2}{*}{ Sex } & Male & 80 & 36.9 \\
& Women & 137 & 63.1 \\
\hline \multirow{3}{*}{ BMI } & Underweight & 13 & 6.0 \\
& Normal & 49 & 22.6 \\
& Overweight & 130 & 59.9 \\
& Obese & 25 & 11.5 \\
\multirow{3}{*}{ Hypertension } & Normal & 127 & 58.5 \\
& Hypertension & 90 & 41.5 \\
& Total & 217 & 100.0 \\
& & &
\end{tabular}

Source: Secondary data

\subsection{BMI with Hypertension}

The results of the study showed that most of respondents who are overweight either those who are normal or those with hypertension 65 respondents respectively (30\%), and the least of respondent is those who are underweight and do not have hypertension as many as 3 respondents $(1.4 \%)$, Chi Square analysis result obtained $\mathrm{p}$ value $=0.009$ with $<\alpha=0.05$, it means there is a significant correlation between BMI and hypertension in elderly (Table 2).

Table 2 : Correlation between Body Mass Index and Hypertension

\begin{tabular}{|c|c|c|c|c|c|c|c|}
\hline \multirow{3}{*}{ BMI } & \multicolumn{4}{|c|}{ Hypertension } & \multirow{2}{*}{\multicolumn{2}{|c|}{ Total }} & \multirow{3}{*}{$\begin{array}{c}p \\
\text { valu } \\
e\end{array}$} \\
\hline & \multicolumn{2}{|c|}{ Normal } & \multicolumn{2}{|c|}{$\begin{array}{l}\text { Hypertensi } \\
\text { on }\end{array}$} & & & \\
\hline & f & & & & f & & \\
\hline$\%$ & & & f & $\%$ & & & $\%$ \\
\hline $\begin{array}{c}\text { Underwei } \\
\text { ght }\end{array}$ & 10 & 4.6 & 3 & 1.4 & 13 & 6 & $\begin{array}{l}0.00 \\
9\end{array}$ \\
\hline Normal & 37 & $\begin{array}{c}17 . \\
1\end{array}$ & 12 & 5.5 & 49 & $\begin{array}{r}22 \\
6\end{array}$ & \\
\hline $\begin{array}{c}\text { Overweig } \\
\text { ht }\end{array}$ & 65 & 30 & 65 & 30 & $\begin{array}{c}13 \\
0\end{array}$ & $\begin{array}{r}59 \\
9\end{array}$ & \\
\hline Obese & 15 & 6.9 & 10 & 4.6 & 25 & 11 & \\
\hline & & & & & & 5 & \\
\hline Total & 12 & 58. & 90 & 41.5 & 21 & 10 & \\
\hline & 7 & 5 & & & 7 & 0 & \\
\hline
\end{tabular}

\section{DISCUSSION}

Most respondents in this study were the elderly (46-55 years old) with $78.8 \%$. Blood pressure in the elderly tends to be high so that they were at greater risk of developing hypertension (high blood pressure). Increasing age results in increased blood pressure, because the arterial wall in the elderly will experience thickening which results in a buildup of collagen in the muscle layer, so the blood vessels will gradually narrow and become stiff [6]. As stated by Manuntung, 40-year-old people are usually susceptible to increased blood pressure which can gradually become hypertension as they age [7]. Age is also one of the irreversible risk factors for hypertension [8].

This is in line with Shaleh's research (2014) about the characteristics and factors related to hypertension that was done to 47 respondents $(73.4 \%)$ with the age of $40-65$ years. According to him people whose age is below 45 years old will usually decrease in their physical condition and the older a person is, the more they are at risk of developing hypertension compared to those aged $>45$ years [9]. Another factor that can affect hypertension and cannot be changed / controlled is gender [8]. In this study, female respondents were $63.1 \%$. Similarly, research conducted by Agrina in Sidomulyo Barat, Tampan, Pekanbaru found 35 female respondents $(58.3 \%)$ and 25 male respondents (41.7\%) [10]. Another study conducted by Ramadhani about the correlation between obesity and hypertension in East Java Province in 2015-2016 showed that in 2015 female respondents dominated with $62.46 \%$ and in 2016 there were $58.54 \%$ female respondents [11].

Female is more prominent than male and this can be associated with greater hormonal factors found in the body of women compared to men. [12]. The hormone is the estrogen hormone in which in premenopausal women it serves to protect bloods vessels from damage. Women will have an increased risk of high blood pressure (hypertension) after menopause which is over 45 years old. The estrogen hormone in women who are not menopausal yet plays a role in increasing levels of High Density Lipoprotein (HDL). Low HDL cholesterol levels and high LDL cholesterol (Low Density Lipoprotein) affect the atherosclerosis process and result in high blood pressure [6]. The results of the 2013 Riskesdas state that the prevalence of hypertension in adult women is higher than in adult men. The prevalence of cases in women was $32.90 \%$, while in men it was $19.70 \%$ in 2013 [4].

\section{Body Mass Index with Hypertension}

The results of this study found that the overweight respondents who experienced hypertension were 65 
respondents $(30 \%)$. This is in line with research conducted by Tisna in which the percentage of hypertension patients who are overweight is $82.53 \%$ ( 14 people). While the percentage of hypertensive patients with normal body mass index was $0.58 \%$ ( 1 person) [13].

Overweight / obesity is a cause factor of hypertension that can be controlled / changed apart from smoking, salt consumption, alcohol consumption, lack of activity and use of estrogen [8]. The finding of the research by Natalia about correlation between obesity and hypertension mentioned that people with obesity have risk of hypertension 2.2 times greater than people with a normal body mass index [14]. The result of chi square analysis in this study obtained $\mathrm{p}$ value $=$ 0.009 with $<\alpha=0.05$. It means there is a significant correlation between Body Mass Index and hypertension in the elderly in Tambak Sogra village. The result of this study is in line with Hasanah's research that was held to the people in RW 13 in Karangploso. The finding showed that obesity has a relationship with the occurrence of hypertension $(p=0,000$ $<0.05$ ). This is due to the fact that most people are not aware of the importance of physical activities such as doing sports in maintaining weight. In addition they consume poor diet and have poor lifestyle. This is evident from the result of research that shows as many as $75.8 \%$ of people do not like to exercise [15]. The finding of Anggraini's study mentioned that there was a significant correlation between obesity and hypertension in Puskesmas Rawasari Jambi in2018 with a $\mathrm{p}$ value of $0.004<\alpha=0.005$ [16].

Obesity is an imbalance situation when the incoming energy is greater than the energy released [17]. Overweight conditions are associated with increased intravascular volume and cardiac output. The heart pumping power and blood volume circulation of hypertensive patients are higher than those of normal weight hypertension sufferers [18]. Research conducted by Rohkuswara and Syarif in Posbindu KKP Bandung mentioned that obesity is a risk factor of hypertension with a PR value $=2,008$ and $95 \% \mathrm{CI}=1,379$ 2,925. It can be interpreted that obesity has a risk of hypertension two times greater compared to people who are not obese [19].

Research conducted by Natalia states that the proportion of hypertension in the obese body mass index group is 0.78 [14]. It is in line with Humayun's research in Pakistan, which shows a trend for higher hypertension with increasing BMI [20]. Both studies reinforce the results of this study that there is a correlation between body mass index and hypertension.

\section{CONCLUSION}

In accordance with the finding of the study, it was found that there is a correlation beytween body mass index and hypertension in the elderly in Tambaksogra village, Sumbang District, Banyumas Regency with $p$ value $=0.006$

$<\alpha 0.05$.

\section{REFERENCES}

[1] Suardiman, Psikologi Lanjut Usia. Yogyakarta, 2011.

[2] Anggita W.I.T, "Hubungan Antara Aktivitas Fisik Dan Tekanan Darah Pada Lansia Dengan Kelebihan Berat Badan," Placentum, vol. 5, no. 2, pp. 1-8, 2017.

[3] W. P. J. K. Kembuan I.Y, Grace Kandou, "Hubungan Obesitas Dengan Penyakit Hipertensi Pada Pasien Poliklinik Puskesmas Touluaan Kabupaten Minahasa Tenggara," Paradigma, vol. 4, no. 2, pp. 16-35, 2016.

[4] Badan Penelitian dan Pengembangan Kesehatan, "Riset Kesehatan Dasar (RISKESDAS) 2013," Lap. Nas. 2013, 2013.

[5] Kemenkes.RI, "Riset Kesehatan Dasar 2018,” 2018. [6] A. D. Anggraini, A. Waren, E. Situmorang, H.

Asputra, and S. S. Siahaan, "faktor-faktor yang berhubungan dengan kejadian hipertensi pada pasien yang berobat di poliklinik dewasa Puskesmas Bangkinang periode Januari-Juni 2008," Fac. Med. - Univ. Riau Pekanbaru, 2009.

[7] A. Manuntung, Terapi Perilaku Kognitif Pada Pasien Hipertensi. Malang: Wineka Media, 2018.

[8] Kemenkes.RI, "Pusdatin Hipertensi," Infodatin, 2014.

[9] M. Saleh, Basmanelly, and E. Huriani, "Hubungan Tingkat Stres Dengan Derajat Hipertensi Pada Pasien Hipertensidi Wilayah Kerja Puskesmas Andalas Padang Tahun 2014," NERS J. Keperawatan, vol. 10, no. 2, p. 166, 2014.

[10] S. S. Rini and R. Hairitama, "Kepatuhan Lansia Penderita Hipertensi dalam Pemenuhan Diet Hipertensi."

[11] E. T. Ramadhani and Y. Sulistyorini, "Hubungan Kasus Obesitas Dengan Hipertensi Di Provinsi Jawa Timur Tahun 2015-2016," J. Berk. Epidemiol., vol. Volume 6 N, pp. 35-42, 2018.

[12] I. Junaidi, Hipertensi: Pengenalan, Pencegahan, dan Pengobatan. Jakarta: PT Bhuana Ilmu Populer, 2010.

[13] G. D. Tisna MS, "Prevalensi Hipertensi Berdasarkan Indeks Massa Tubuh Pada Dosen Umur 40-59 Tahun Di Lingkungan Universitas Pendidikan Ganesha Singaraja," GLADI J. ILMU 
KEOLAHRAGAAN, vol. 7, no. 2, p. 733, Oct. 2013.

[14] D. Natalia, P. Hasibuan, and H. Hendro, "Hubungan Obesitas dengan Hipertensi pada Penduduk Kecamatan Sintang, Kalimantan Barat," eJournal Kedokt. Indones., 2015.

[15] M. Hasanah, D. Widodo, and E. Widiani, "Hubungan obesitas dengan hipertensi pada masyarakat di wilayah RW 13 Dusun Mojosari Desa Ngenep Kecamatan Karangploso," Nurs. News J. Ilm. Mhs. Keperawatan, vol. 1, no. 2, pp. 35-44, 2016.

[16] S. D. Anggraini, M. D. Izhar, and D. Noerjoedianto, "Kejadian Hipertensi Di Puskesmas Rawasari Kota Jambi Tahun 2018," Kesmas Jambi (JKMJ), vol. 2, no. 2, pp. 45-55, 2018.

[17] H. R. Hasdianah, S. Siyoto, and Y. Peristyowati, Pemanfaatan Gizi, Diet, dan Obesitas, 1st ed. Yogyakarta: Nuha Medika, 2014.

[18] F. C. Widyanto and C. Triwibowo, Trend Disease “ Trend Penyakit Saat Ini". Jakarta: Trans Info Media, 2013.

[19] T. D. Rohkuswara and S. Syarif, "Hubungan Obesitas dengan Kejadian Hipertensi Derajat 1 di Pos Pembinaan Terpadu Penyakit Tidak Menular (Posbindu PTM) Kantor Kesehatan Pelabuhan Bandung Tahun 2016," J. Epidemiol. Kesehat. Indones., 2017.

[20] A. Humayun, A. S. Shah, and R. Sultana, "Relation of hypertension with body mass index and age in male and female population of Peshawar, Pakistan.," $J$. Ayub Med. Coll. Abbottabad, 2009. 